\title{
The Noble Savage and the Civilised Brute: Nature and the Subaltern Angst in Swarup Dutta's Machh Master (The Expert Angler)
}

\author{
Sajalkumar Bhattacharya \\ Ramakrishna Mission Residential College, West Bengal, India
}

\begin{abstract}
Parallel reading of history from the subaltern point of view is not only possible, but it also often proves to be revealing. It often unearths a new discourse, which challenges the canonized history or even subverts it. This paper offers a reading of a recent Bhasa (Bangla) novel Machh Master (The Expert Angler) where the Naxalite Movement that rocked Bengal in the sixties, has been narrated and analysed from the viewpoint of one dalit subaltern. The novel attempts to create a binary between this 'uncorrupted' world/mode of existence and the civilized, sophisticated, intellectual, but essentially 'corrupted' urban world. In this natural savage world and its eco-system, the urban, elitist Naxalite movement turns out to be nothing but an imposition and an intrusion. At the end, disillusioned Neul detaches himself from this movement, goes back to, and embraces Nature in a desperate bid to get back his pre-lapserian mode of existence. Neel, chief agent of the Naxalite movement, too is influenced by these children of Mother Nature, and undergoes a transformation. This paper explores this interesting role of Nature in this new reading of the history of mankind.
\end{abstract}

Right from its inception, Civilisation has alternately lured and repulsed man. There has often been a feeling of being trapped within its cruel, intricate web, followed by an irresistible desire to go back to the primitive state. Consequently, Primitivism has been taken up by many artists down the ages, as a fond project. Primitivists like Marshall Sahlins ${ }^{1}$, unfailingly seek to expose and challenge all the multiple forms of power that structure the civilised society. They draw our attention to the fact that prior to civilisation, there not only existed ample leisure time,but the essential merits of the primitive society were considerable gender equality, and social equality, a non-destructive approach to the natural world, the absence of organised violence, no mediating or formal institution. It is civilisation that inaugurated warfare in its shrewd forms, concepts of property, and most dangerous of all, entrenched hierarchies. The most horrific aspect of civilisation is that it begins with and relies on an enforced renunciation of instinctual freedom. Domestication, according to primitivists, is nothing but a

\footnotetext{
Rupkatha Journal on Interdisciplinary Studies in Humanities (ISSN 0975-2935)

Volume I, Number 2, Autumn 2009

URL of the Issue: www.rupkatha.com/journalvol1no2.php

PHP URL of the article: www.rupkatha.com/swarupduttamachhmaster.php

PDF URL of the article: www.rupkatha.com/0102subalternangstswarupduttamachhmaster.pdf

(C) www.rupkatha.com
} 
power, a shrewd application of stratagems that civilisation uses to control life according to its strictly ordered logic. The mechanisms of domestication - taming, schooling, caging, intimidating, coercing, contracting, governing, enslaving, even terrorizing and finally murdering, cumulatively build up a process that wishes, apparently, to reduce the uncertainties and dangers of life, and ensure a completely safe and organized existence, but ultimately to change the ecology from a free to a totalitarian order. In the process, the spontaneous, natural human bonds are mutilated, leading us to a fractured and distorted life.

The other devastating aspect of civlisation, but closely related to the totalitarian order, is the senseless usurpation of Nature. The primitivists have always pointed to the stage when nomadic human population relied only on hunting for its sustenance ${ }^{2}$. A gradual shift from this mode to a sedentary and settled existence through agriculture had greatly affected the ecological balance, because this had necessitated the end of open sharing of the resources that formerly existed. With the emergence of the concept of ownership, man started to hoard up natural wealth, laying the foundation for social hierarchy. This entailed greedy exploitation of the natural resources and ultimately destruction of the natural habitat. That is why the primitivists advocate rewilding, learning how to live together in non-hierarchical and non-oppressive communities, and doing away with the domesticating mindset in social patterns. To the primitivists, "rewilding" suggests living within one's bioregion, being intimately connected to the land, water, climate, plants, animals, and general patterns of their bioregion. For them, rewilding and reconnecting with the earth is a life project. ${ }^{3}$

Let us now explore the world of Machhmaster (the Expert Angler) from this angle. A Bangla novel written by Swarup Dutta in 2005, Machhmaster has already bagged two awards, one of them being the Kathasahitya award given by the Bangla Academy this year. It is a story of an investigating, dream-stricken dalit ${ }^{4}$ angler, Neul, who spends his days deciphering the secret code of still pondwater. To him, a pond is not the business-warehouse of aquatic harvest, but a strange blue world full of colour, beauty and mystery. Neul is almost a feral child ${ }^{5}$, an ideal primitive, who refuses to be domesticated by the society. He is a savage ${ }^{6}$ entity whose life is so surely identified with wild Nature that he becomes an inseperable part of it. 
We first meet him at the top of a date-palm tree, engaged in extracting palm juice. He has lost his mother when we meet him, and he has soon placed himself in the lap of nature, who seems to have made up for this loss. From the natural world of flora and fauna, he draws his sustenance instinctively, and in such an unsophisticated way that at once places him temporally and spatially at a point remote from the civilised society. In the entire novel, Neul refuses to conform to any established, enforced social customs or traditions. He refuses to be tamed by 'reason' of civilisation. He neither has the minimum expertise to manage the household, nor does he know how to cook food. Most of the day, this half-naked savage forages for his food in the damp marshy lands around the ponds of the village and is satisfied with wild berries and stems:

Neul encircles the solitary Bhabai pond, Laxman sayar and Ballal sayar. Now, in this late afternoon he is lying supine on the side of one of the ponds. For a long time, he is observing the tenacity of a small kingfisher. Suddenly he feels hungry. He gets down to the water. The edges of the pond are strewned with onion-grass. He uproots a fat tuft. Like a washerman, he gives the tuft a few blows and puts the root in his mouth. The pungent taste of the onion is missing. It's rather a bit watery! Not bad after all. Neul pulls out another tuft, again and again and again... then, for a change of taste, he shifts to lotus-stalk... again a change of taste with the relish of lotus-lobe....with the satisfaction of a gentle calf, Neul feels sleepy as he continues to chew lotus-lobes. ${ }^{7}$

This close proximity with Nature gives him more of an animal status than that of human being. And he is one of the keenest explorers of Nature. He has the minutest knowledge of the aquatic world of Nature as well as that of the land at his fingertips. Studying the direction of the wind, he can understand that a storm is in the offing. He does not bother to perform the sradh ceremony of his dead mother, but knows his natural habitat so perfectly that while others fail to detect a fish in the dry pond, he exhibits an adroit skill in tracing the catfishes deep under the mire. He is the self-appointed watchman of all the ponds of his village:

Which fish is developing a hump, which katla is bearing a wound in the mouth, the ruhu with white spots on the gill, the water-wort which is causing disturbance to the fishes, on which ponds boals are attacking others, on which pond traces of ferry-net have been noticed at night...- 
all these are known to Neul. Pond owners come to him for many such information and ask him the preventive measures. He helps them all, and that too for free. ${ }^{8}$

And most importantly, he is not a fisherman who exploits the natural resources more than is necessary for his daily sustenance. Rather, he has profound love for these fishes. Hunting them with the agility of a leopard, he lets them go back to their habitat with the love of a mother. The day when for the first time in his life, his prey, a big mirik fish, eludes him, he is only too happy, for a bond of natural kinship with the fauna of the water-world gives him a sense of relief that he has not killed the fish! In a masterly description of a boar-hunting, we find Neul instinctively empathise with the hunted animal. Or elsewhere, bitten by a snake, he still empathises with its fear, for he finds it pregnant, and lets it go most tenderly. Interestingly but not surprisingly, in the novel the first fantasy that arouses his manhood is that of the mermaid, and he finds relief to this first sexual stimulation in the throat-deep water, where he is more comfortably placed than on the land.

Juxtaposed against this is the picture of the civilised brute. The novel, we must remember, is set against the turbulent times of the late sixties in Bengal. In the second half of the sixties, India faced a terrible shortage of food. In 1965, the total production of foodgrain came down to as low as 6.33 crore tonnes. Even a large-scale import could not raise the daily supply of food per head to more than 408.2 gms. $^{9}$ An acute crisis of rice gave rise to blackmarketing. Rice was becoming costlier every day, widening the gap between the landowners and the landless farmers to an unbridgeable extent. Through this gap the Naxalite Movement made its entry with its agenda of revolution aimed at demolition of this economic difference among the rich landowners, the petit bourgeoisie, and the marginalised, dalit have-nots, marking the beginning of a conflict. The uncivilised, illiterate, yet innocent, marginalised people on the one hand, and the educated, well-informed, civilised yet shrewd, brutish people on the other-engage themselves in a dialectical relation in the rest of the novel. And it is from this conflict, we get a new reading of the Naxalite movement-the dalit reading. Initially, with the the entry of the Naxalites (and different other political groups), a wave of dream lapped around the lives of the below-the-poverty-level dalits in the form of socialist myths and folktales brought by the politicians. On the other hand, 
a new, tactical war starts among some so called intellectual, 'civilised,' wellinformed but essentially shrewd people, to secure complete power over these innocent people. Partly out of curiosity, but mainly lured by the myth of equality and a dream of Utopia, Paltan, Paga, Bhola and even Neul gather together to hear these stories. For the time being, they were sensitised to this unbridgeable chasm, to the long history of exploitation to which they have been victimised for generations. Capitalising on this history of exploitation and poverty, a stark binary of the surfeit of luxury of the landowners and the lack of even the basic amenities in the lives of this poor, the Naxal leaders start organising regular meetings in the village with these people in order to initiate them into socialistic ideals and rake up in them the fire of deep distrust, hatred and anger against these landlords. But what is the ultimate result? They are initially lured by the utopian dreams of a classless society, where there will be no police in the first place, (police being the most immediate, tangible source of fear/torture to these people) but still the intricate reasonings, shrewd strategems can hardly penetrate through these naïve minds. They are thus subjected to a very unstable state-rocked constantly between faith and doubt, dream and reality, hope and fear.

... the price of rice is on perpetual rise. In Shrabana, people are suspecting that it would touch Rs.3. they are indeed scared. Almost on every evening, hurricane lanterns lighten the courtyard of Hamid master or that of Subolbabu. Lanterns are encircled by some half-naked apparition-like people. There are visitors even from the lowly castes Bagdipara, Dulepara, for instance.Many things remain unintelligible but they just love to listen to the new fairy tale where there is no king, no prince, not even princess. They all have been substituted by commoners! The apparitions ask few questions, the aparelled ones are more inquisitive....Tough answers for tough questions! The apparitions only nod their head out of wonder and confusion.... Bhola Bauri suddenly asksAren't there any police force? Subolbabu nods his head in negation-there is, but of a different kind. A different kind of police! Bhola cannot get the picture alright. He lights a bidi. ${ }^{10}$

Then again, later on, 
Neul never attended the meetings of the 'new party', although Paltan insists him to join. Neul could not decipher any meaning from the words delivered to him by Paltan.

...Everyone gets food, clothing! All the children go to school? The state is ruled by farmers and workers? But the scenario has changed. The poor has become poorer. How come the poor becomes even poorer? The fact is that the rein was never in their hands. The masked babus were actually the leaders...

Now listen to the other manifesto of a new country called China. The poor village folks have started a revolution. Now actually the proletarians rule there. We shall have to follow their leader! But why? Then the song begins:

Dear motherland will be free

The day is coming nearer

It is red, (as) the red of bright sunshine

On the east coast of the sea...

The song is followed by a speech. Dry words after a good song make Neul embittered... the same old story of that new land! ${ }^{11}$

And as this goes on and on, their prelapserian, primitive mode of existence is seriously threatened. Yet they could not pick up enough experience to become seasoned, corrupted, hardened, typically civilised brutes. Taking advantage of this chaos, the naxal leaders as also several other local leaders of different political parties, impose their contradictory decisions on these people and vex them, corrupt them. The calmness of this sylvan mode of existence is seriously disrupted as a meaningless, gory violence erupts and spreads around, killing the good and the bad at random. Poverty, illiteracy, social inequality - all remain unaltered. This leaves the poor, ignorant dalits trapped, in a sense, by the civilised brutes.

Neul, who never feels at home in this turbulence, and can never adapt himself with these new developments, is stupefied by these atrocities unleashed by the 'leaders'. He is not only disillusioned, but is crippled by a feeling of deep apathy towards these civilised brutes. When Bijumaster, who stands out in this novel for everything that is good and uncorrupted in human nature, falls a victim to this brutish political power-mongering, he, out of disgust and apathy, turns 
away from this ugly face of civilisation and its institutions. Neul rejects all inventions and constructions of the 'civilised'and corrupted human natureeducation and political institutions like elections. In a poignant passage in the novel, Neul, who only a few days back, was gradually feeling enthusiastic about his daughter Sanaka's education under the guidance of Bijumaster, dumps all her books, false logo of a civilised society, into the burning pyre along with Biju's dead body. Soon, we find her seeking earthworms beside the ponds for baits to entice fishes. Neul refuses to take part in the electoral system, and out of utter frustration, turns back to her mother, Nature, who has never betrayed him, who has always provided him the shelter of a home. In the final section of the novel, Neul struggles to free himself of this trap of civilisation like the trapped openbill bird he frees with gentlest care and affection.

Suddenly a faint sound makes Neul uneasy. Neul's alert ears catch the sound once again. Neul stands erect and after a little search he finds the source of the unknown sound. A few yards above a paddy-shoot, a big Asian openbill bird (shamuk-khol) is flapping its wings but cannot fly. Neul, with an anxious hunch, immediately starts running towards it. Neul could make out the problem before reaching there. He has heard about such inhuman traps, but never seen one. Small bamboo-twigs have been planted on the mud and all the twigs are conjoined with thick course silkthread. And on the tip of each twig, there is a fishing rod with small fishes and puffed rice tied to it-a trick for catching birds with fish-bait.

Neul also takes angling as his profession and his pastime but the bird's painful condition maddens him with wrath. He carefully tries to bring he bird down by pulling, the thread -'Don't be afraid, little one, don't be afraid.' The bird desperately flaps its large wings but cannot make any sound because the thorn is stuck in its throat. Neul feels exhausted to bring the bird under his control. Pressing it on his lap, he tears the thread with his teeth... if I let it go, the bird will fly away, but it will surely die of ulcer - so Neul tries to take out the thorn from its throat. But the task is anything but easy. An expert as he is, it takes long enough to complete the job. As soon as the thorn is released, the bird becomes more restless. Neul, feeling the feeble shivering, whispers- 'you are alright, don't be 
afraid.' Machhmaster stands up holding the bird in his hands. With a smile he lets fly the bird-'go, byebye, go'... ${ }^{12}$

Finally, he seeks shelter in Nature. In the final section of the novel we notice in wonder how he gets permeated by the elements of nature which cleanse him, as it were, of the dirts of the civilised society that he has gathered over these few years, and soothes him of all his afflictions and anxiety:

Neul shuts his eyes in great aversion. Everything forms an intricate mesh inside his weary head. Here in the animal world, the situation is clear; greed is directly proportional to hunger. But what is wrong with the people out there! Everything is different. Why the hell are they like this? And why the 'why's are so strange? Neul's body seems to crumble with feverish depression and anguish. In spite of the stormy cold wind, he gasps for air. Machhmaster drowns his head between his knees like a sacrificial animal. Storm raves the area with increased force. Leaves gyrate and fall like raindrops. The leaves of neem, hog-palm, bamboo, wood-apple and banyan trees cover the distraught, distressed body of motionless machhmaster - as if he is not a human, but a withered man-foliage. ${ }^{13}$

If the rejection of civilisation by the Dalits of Bontia village is one part of Dutta's scheme to promote Primitivism over Civilisation, even a more interesting part of it is Neel's story that runs parallel to that of Neul. Neel is a classic case of transformation in this story. He came to this village as a cadre of the Naxalite group. Once a brilliant student of Physics in Presidency College, he gets involved in this movement, believes in its ideals and tries to assimilate them in his own life sincerely. As a faithful comrade of this movement, he sacrifices his promising career and a comfortable life like many of his friends and wholeheartedly takes up the task of kindling the spirit of revolution in these innocent hearts. But ironically, he himself gets transformed in the process. Gradually, the flaws in the project start glaring at his face. Spontaneous, instinctive love for him in Neul, Paga, Paltan, along with a divine goodness in Biju master, who stands outside this corrupted ambit of the civilised society, gradually usher in him a new life. He realises that relation between man and man in the lap of nature is based on a host of spontaneous, easy bonds of love. Political movements or all other civilising missions, even with good intentions, fail to feel the pulse of this spontaneous, primitive life. Consequently, they end up as unwanted, incongruous 
interruptions and encroachments in their primal, lives. One important lesson that Neel learns from these noble savages of Tiyagram is that a deep understanding between two souls stemming from an intimate, need-based relationship of day-today life is far more genuine and sincere than relationships based on organisations, ideologies or abstract ideas imposed on them from outside. That is why 'class hatred' is an utterly foreign phrase to Neul, Bholakaka and Paltan. Ultimately in an epiphanic moment, he realises his failure in mingling with the masses:

a wretched feeling of guilt consumes Neel, as he realises how foolish had he been to try to bring about changes in the lives of these men with certain ill-digested theoritical beliefs...'What have I done with these men...this Neulda, Bholakaka, Duluda, Budhan, Yasin-these innocent souls? What a sin to have turned them puppets in my hand!...'relations of heart!'- Neel laughs at this cliché which his leaders have uttered unfailingly each time during their training sessions in the communes-what the deuce do we know of such a relation? How little do I know of the flora and the fauna, the tanks and the alleys, Nature and her own, very own men? And still we dare to do them a favour by forcing them to take part in the revolution of which they have no idea!!... Neel becomes crippled in a sense of shame and remorse. ${ }^{14}$

This remorse not only burns Neel, but also purifies him. Civilisation, education, his experience of politics - the empty egotism of all these peels off from his being. He clings to the mother-child relationship, the most primal and natural on earth, and he is reborn into richness. The novelist continues -

Like a scarecrow, he sits there on the desolated land for a long time-for how long he did not know. And then finally, he desperately looks for the lap of his mother, tries to reach her by retracing the steps he has taken in a state of frenzy in these last two years- Ma! My sweet Ma!... ${ }^{15}$

Tears drown him as he turns to Rabindranath at this point of defeat. Fondly he remembers a few lines from Tagore's songs of prayer:

When all sustenance is spent,

Defeat has left its gory scars on my life

When exhaustion has drained out the last drop of effort

Leaving me forlorn and numb 
O Lord! Nourish those wounds with love and forgiveness

Let my face turn from defeat to a new morn of hope,

Cover up all my shame in the dark oblivion of forgetfulness... ${ }^{16}$

Finally, he wakes up to a new hope, a new determination to start a new life among the masses. He remembers Tagore again:

Poet, then arise - if you have life

Then bring that along with you, and today

Offer that too.

Immense sorrow, immense pain-tough world to face

Too wretched, hollow, too small, walled and dark.

We need food, vitality, light, open-air

Strength, health, happy, bright life span,

A courageous chest. Oh, poet,

Amidst this sorry state, for once

Bring the belief from heaven. ${ }^{17}$

And this transformation in Neel is complete as he throws away his revolver in the pond, out of disgust. Along with the revolver, he throws off his fake identity:

After a long contemplation, Neel gazes at the revolver tucked in his waist for some moments. Then he slowly looks at the pond and throws it away with an impulse of pain and rage. Ah! What relief it was for him as he starts a new quest for a new hope that would redeem him. ${ }^{18}$

And it is in this redemptive quest of Neul and Neel that the novelist completes his critique of civilisation. Though of course, one must take a pause here to consider whether the project of Rustic Primitivism to be achieved through 'rewilding' is altogether possible, or even desirable at all. Quite a few critics point out that if everyone lived as a hunter-gatherer, the earth would be able to support a far fewer people, possibly as little as one hundredth of today's 6.5 billion. As Noam Chomsky candidly observes:

I do not think they are realising that what they are calling for is the mass genocide of millions of people because of the way society is now structured and organised, urban life and so forth. If you eliminate these structures, everybody dies. For example, I cannot grow my own food. It's a nice idea, but it's not going to work, not in this world. And in fact, none of us want to live a hunter-gatherer life. There are just too many things in 
life that the modern world offers us. In just plain terms of survival, what they are calling for is the worst mass genocide in human history. And unless one thinks through these things, it's not really serious. ${ }^{19}$

A total rejection of civilisation and consequent embracing of Nature in its primitive state hardly seems a feasible option in a tech-savvy twenty first century world. But still, in this age of ecological devastation, Dutta's scheme of balancing the brutishness of civilisation with Nature's primitive laws has its own value. Man should go back to Nature again and again, not only to collect his material needs, but because Nature alone can nourish the values of life that sustain him. A spontaneous acceptance of Nature surely has a therapeutic value-it can wash away the dirt, affliction and agony that civilisation dump on his being. This acceptance alone can save us from the impending imbalance and disaster.

\section{Notes}

1. Marshall Sahlins, noted American anthropologist, has been referred to in John Zerzan, Future Primitive and Other Essays, Brooklyn, Autonomedia, 1994. Also see Sahlins' book Tribesman, New Jersey, Prentice Hall, 1968.

2. Marshall Sahlins observes that these bands were basically egalitarian - socially and economically. Primitivists have characterised these primitive societies as 'gift economies', because goods, in these societies, were 'valued for their utility or beauty rather than cost; commodities exchanged more on the basis of need than of exchange value; distribution to the society at large without regard to labour that members have invested; labour performed without the idea of a wage in return or individual benefit, indeed largely without the notion of 'work' at all.

3. These are some of the basic ideas on Primitivism I have summarized from the Wikipedia entry on Anarcho-Primitivism - http://en.wikipedia.org/wiki/Anarchoprimitivism\#cite_note_3, updated January 2009, consulted on 29 ${ }^{\text {th }}$ Feb, 2009.

I am also indebted to

www.greenanarchy.org/index.php?action=viewwritingdetail\&writingld=283

(html) for the entry 'An Introduction to Anti-Civilisation Anarchist Thought and Practice.

4. Neul (and other marginalized characters in this novel) is a Bauri by caste. Though the caste system is not as prominent in present urban Bengal as it is in Bihar or some other states in Northern India, still the Bauris, the Harees, the Doms - all belong to the lowest stratum of the society and are still considered to be untouchables in remote rural Bengal even today.

5. An interesting treatment of this concept was done in Hayy ibn Yaqdhan, an Arabic philosophical novel by Ibn Tufail, a $12^{\text {th }}$ century Islamic Philosopher. The 
plot revolves round a feral child, Hayy, who is raised by an animal on a desert island and grows up to become an autodidactic philosopher, before eventually making contact with civilisation.

6. Although the term 'savage' emerged towards the end of the middle ages in Old French and Middle English, its connotations had long been a part of the global thought. In the first century B.C., in Geography VII 300-303, Strabo praised the ancient Scythians as thrifty and self-sufficient, the most honest and least deceitful of people. Since then, the concept of noble savage has been highlighted all along right from Thomas More's Utopia (1516) to Voltaire's El dorado (in Candide,1759) where the primitive societies were depicted as surrounded by unrefined gold ore, which the natives ignored as a useless metal. Dryden used the phrase for the first time in the Conquest of Granada (1672). The noble savage, uncorrupted by the influences of civilisation, has always been considered more worthy, more noble than the contemporary product of civilisation, mainly because the noble savage desires nothing beyond the necessities of life, acquired from nature without work. Content in his existence, he displays neither ambition nor avarice.

7. Swarup Dutta, Machhmaster, Kolkata, Subarnarekha, 2005. p 61. This and all other translations from the original Bangla text are mine.

8. Ibid p14

9. Souren Basu, Charu Majumdarer Katha, Kolkata, Peoples book Society, 1989.See the introduction by the noted economist, Ratan Khasnobis.

10. Machhmaster, p 25

11. Ibid pp 85-86

12. Ibid $p 189$

13. Ibid p198

14. Ibid $p 157$

15. Ibid $p 157$

16. Ibid p194

17. Ibid pp 157-158

18. Ibid $p 195$

19. Barry Pateman ed., Chomsky on Anarchism, Oakland, AK Press, 2005. p226

Writer: Sajalkumar Bhattacharya is Selection Grade Lecturer in Ramakrishna Mission Residential College, Narendrapur, Kolkata, West Bengal, India. E-mail: sajalbh@gmail.com 